\title{
CONTINUING PROFESSIONAL DEVELOPMENT ACTIVITIES FOR ENGLISH TEACHERS
}

\author{
Nana Priajana \\ IAIN Syekh Nurjati Cirebon \\ Email: priajana@gmail.com
}

\begin{abstract}
Teachers' quality plays a paramount role in the improvement of quality of education. A way to ensure high quality teachers is through effective continuous professional development for teachers. This present study is aimed to explore how the EFL teachers develop their professionalism particularly in terms of pedagogical and professional competencies. The result shows that there are three main themes of professional development pursuits of EFL teachers comprising of selfinitiated or individual, institutional, and non-institutional professional development activities.
\end{abstract}

Keywords: continuing professional development, EFL teachers, pedagogical competency, professional (subject matter) competency

\section{BACKGROUND}

Professional development (PD) in an academic setting is believed to be a means to sustain and to enhance the quality of education effectively with continuing changes. There has been a great interest recently in the discussion of teachers and professional development by several researchers, educational practitioners, and teachers (Anugerahwati and Saukah, 2010; Mustofa, 2010, Qing, 2010; Khan, 2011; Hussein, 2012; Amin, 2013 and Simegn, 2014). This may indicate that teacher professional developments along with the needs for ongoing renewal of professional skills and knowledge is seen as the cornerstone of teachers' professionalism and quality (Lee, 2011). Thus, in this sense, Johnson and Golombek (2011) conclude that teacher professional development is a key to improve the quality of student learning and the ultimate goal of any educational enterprise.

In English Language Teaching (ELT) context, some scholars (Chan, 2011; Karimi, 2011; Kasi, 2011; Lee, 2011, Wati, 2011; Meng and Tajaroensuk, 2013) investigated various programs concerning English as a Foreign Language (EFL) teacher professional development. They examined several effective approaches to teachers' involvement in professional development programs such as seminars, pre-service teachers programs, teachers training programs, workshops and other similar activities. Their findings suggest that it is necessary for the teachers, as professionals, to keep updated and at least to maintain their professionalism in responding to new educational paradigms and trends.

In response to the current needs and trends on the ELT context, some researchers (Qing, 2009; Su, Yang, and Hsioa, 2010; Wati, 2011 and Wichadee, 2011) tried to contribute by providing new insights, approaches, strategies and some practical ways concerning professional development for teachers to go along with the teachers' 
needs. According to Zuheer (2013), developing EFL teachers' performance dealing with many related fields and needs such as the abilities and skills becomes very important. Therefore, professional development program held in fulfilling teachers' needs can be valuable for teachers to improve their quality.

Many effective strategies and activities such as reflective inquiry, individual and collaborative teacher professional development programs can be implemented to upgrade teachers' performance and competencies. With regard to the activities, Raza (2010) states that self-directed development has its own significance in individual teacher development with his/her own specific teacher development agenda and needs. On the other hands, according to Richards and Farrells (2005), although teacher development activities can occur through a teacher's own personal initiative, collaborative PD activities both enhance individual and collective developments. Thus, it is apparent then that the interacting aspects of sustaining professional development activities both the individual teacher and the collaborative activities are significant to cater the various needs of teachers in their own ways.

Pertaining to teachers' responsibility as professionals stipulated in The Teachers Law 14/2005 and Government Regulation No.19/2005, there are four main competencies that teachers are necessary to cope with including pedagogical, personal, social and professional competencies. These competencies are also in line with Brown's (2007) concepts pertaining to knowledge and skills of good English teachers including technical knowledge (subject matter), pedagogical skills, interpersonal skills and personal qualities. These knowledge, skills and competencies are necessary to shape qualified and professional teachers. Therefore, teachers are required to have a great recognition in developing their competencies due to it is part of their responsibilities as professionals.

Professional teachers in general must possess the required competencies to be qualified. Many teachers believe that good teachers are indicated with how much teaching experiences the teachers have. However, Rodríguez and McKay (2010) believe that experienced teachers are not always better than less experienced teachers yet experienced teachers frequently manage their classrooms more effectively than less experienced teachers. In this respect, both novice and experienced teachers are required to have standard competencies to be professional teachers.

According to Ramadhani, Ancok, Swasono, and Suryanto (2012), qualified teachers are those who show a high commitment to their profession as teachers. The teachers are required to have ability to take the initiative and be innovative in inventing media of learning, must have ability to communicate clearly and pleasantly, should be able to facilitate learning process which involve planning effectively, establishing rules that are reasonable and not excessive in number, and arranging the classroom so that instructions go smoothly.

In the light of the previous studies concerning professional EFL teachers, Amin (2013) points out not only the factors influencing teachers but also the trajectory of EFL teachers to become professional and unprofessional. In addition, some other studies (Kolo, 2006; Anugerahwati, 2009; Liando, 2010, and Husein, 2014) show specific features of outstanding EFL teachers such as the portraits of effective teachers, the best teacher characteristics, the ideal teachers or teachers of EFL. The notions of the journey, the portraits, the best characteristics, and the ideal professional English teachers have provided distinct quality of EFL teachers in Indonesian context. However, their professional development pursuits have been less discussed particularly 
in terms of the ways of teachers conduct their competencies both individual and collaborative activities. Therefore, it is necessary to look into English teachers negotiate with their situations to sustain their current professionalisms.

Based on the elaboration of the problems, the research question is formulated into, how do EFL teachers develop their professionalism continuously. This study is aimed to investigate how English teachers develop their professionalism and competencies. In addition, it is believed that qualified EFL teachers are expected to demonstrate their sturdy commitments for their professionalisms. This study is aimed to provide new insights to the existing theories of teachers and contribute to a wider perspective on professional development for EFL teachers

\section{METHOD}

This research employed a qualitative design involving seven EFL teachers teaching in junior and senior high schools. The sites of this research covered two parts of area in West Java, including one municipality and a district of Cirebon. The presence of the researcher, as the key instrument, was very crucial. The data were collected through in-depth interviews, documentary sources and classroom observation checklist. The data also were collected from other sources such as subjects' colleagues, teachers' supervisors and the classroom observation. These various sources of data were necessary and useful in providing a measure of triangulation which is an essential component in all qualitative research studies as this adds to both the truthfulness and the reliability of the findings (Creswell, 2012).

\section{FINDINGS AND DISCUSSION}

The findings show that there are clear substantial patterns of PD activities conducted by EFL teachers in terms of pedagogical and subject matter competencies. The categories were divided into two main themes including institutional and noninstitutional PD activities.

Regarding PD collaborative activities conducted by all subjects, there are two main patterns that can be classified including institutional which are conducted inside school environments and non-institutional which are performed outside school environments. Collaborative PD activities conducted institutionally can be in forms of school IHT, communication in English with her students \& English teachers, informal discussion/conversation, peer observation, peer coaching, and Classroom Action Research. From the data obtained, these collaborative activities have contributed to subjects' professionalism in improving their quality. Thus, they can be worthy recommendations for other teachers to apply some activities that have been empirically performed by all subjects.

In terms of non-institutional PD activities, the subjects shared some activities such as getting involved actively in English teacher forum (MGMP), attending seminars, workshops, teachers trainings, having language proficiency test, teaching experiences at English course, being a coach and an adjudicator of English debate, pursuing further study, having comparative study, and implementing lesson study. In this respect, these non-institutional PD activities conducted by subjects collaboratively showed positive impacts for teachers. These activities, therefore, can be considerable for teachers' professional developments in terms of pedagogical and subject matter competencies. 
Concerning the institutional PD activities conducted by subjects individually, they shared few activities including individual reading, joining online language and professional community, writing reflective teaching journals, doing self-reflecting, and writing articles in the local newspaper and tabloid. Although each individual subject had different activity, the other activities conducted by other subjects could be appropriate to apply as alternate programs. Figure 1 shows how EFL teachers conduct PD activities in both of the combination of pedagogical and professional competencies.

Collaborative PD activities performed at school contexts (institutionally) in the forms of communication in English with her students \& English teachers, school IHT, informal discussion/conversation, peer observation, peer coaching, and CAR have indicated positive impacts for the betterment of teachers' professionalism. Although in some parts the majority of subjects conducted the activities while in other parts not, the activities can help teachers improve their knowledge, skills and teaching performance. Therefore, the findings confirmed the existing theories regarding collaborative PD activities which indicate the strength and the weaknesses of each activity.

With regard to non-institutional collaborative PD activities, the subjects exposed some similar PD activities. Academic and professional collaborative programs were the most common activities conducted by all subjects. All subjects had same experiences related to their involvement in English teachers forum and participation in seminars, workshops and trainings. They believed that those activities have provided spaces for teachers to keep informed about the latest issues of English teaching. In addition, teachers also could discuss and share problems and solutions with other teachers. As the consequence, teachers consider this activity could maintain and develop their quality.

The involvement and the participation of teachers in professional forum and academic programs could offer some benefits for their quality improvement. For instance, a short-term learning activity such a workshop provides an opportunity to acquire specific knowledge and skills (Richards and Farrells, 2005) addressing issues related to both institutional improvement and individual development. In addition, workshops are good way to stimulate everyday teaching with new classroom ideas and reflection on practice (Davison, et al. 2012). Therefore, because of their positive impacts on their professional competences, the majority of the subjects participated in some workshops get the better teaching skills.

The PD activity that most teachers took part was in-service training in form of seminars and workshops. These kinds of activities were frequently provided by the local authority as regular activities. With regard to workshops, Lay (2010) claims that workshops could also help both trained and untrained teachers to be able to advance their knowledge in their teaching careers and become familiar with techniques and approaches and properly use them fruitfully.

With regard to another teacher development program such as seminars, the subject perceived that attending to seminars about the current issues also have become a popular issue among the subjects. Most of the subjects took participations on seminar held both local and provincial education department. However, more recent studies show that teachers face difficulties in facilitating learning in classrooms because the inservice training courses they attend do not emphasize the importance and the effect of the techniques on language learning and teaching (Al-Wreikat \&Abdullah, 2010). In line with that study, Kazemi and Ashrafi (2014) reveal that there are some inadequacies in-service teacher training programs and teachers' expectations for instance, the topics 
and content of programs were not relevant to teachers' need so that teachers' need was not taken into account in organizing the program. In short, in service training that are intended to keep practicing teachers up-to-date and/or to address the issues which occur in their practical teaching should be revisited and reevaluated regarding the implementation of programs to be more relevant for catering teachers' needs.

In terms of skills and knowledge extension programs, the majority showed similar activities such as having language proficiency test, teaching at English course, being a coach and an adjudicator of English debate and lesson study. The subject believed that teaching experiences at English course made them have richer of teaching techniques and having English proficiency test was intended to maintain teachers' language skill. In addition, coaching and an adjudicating in English debate has provided teachers an extra skills particularly in critical thinking and oral communication skills.

In addition, participating in lesson study could be meaningful part of the improvement of teaching skills. With regard to lesson study, Tasker (2011) points out that the goal of the exploration of student learning within the context of lesson study has the potential to promote greater teacher professional development by focusing teachers' collective attention on shared student learning issues, and pursue jointly constructed solutions. Therefore, these activities could assist teachers not only to be more proficient in language skills but also to be more skillful in teaching in the classroom. As the result, teachers with the required language proficiency and a specialist ELT teaching qualification will have more chance of getting results in the classroom (Wichadee, 2011).

In connection with a doing course (a formal study or a short course/comparative study) as the last collaborative PD activity, it is frequently considered the most prohibitive activity due to time and expense (Johnny, 2009). Based on the findings, more than half of the subjects could pursue their further studies, while the other have not had the opportunity for continuing their study. The data obtained from analysis, taking a formal education or a short course have contributed to the improvement of their quality not only in terms of teaching skills such as classroom management, material developments but also language skills along with the cultures. Therefore, Johnny (2009) confirms that doing a course is a great way to develop teachers' competences since the most of the time teachers are focusing on thinking and learning.

In conclusion, collaborative PD activities conducted outside school context are distinct from the institutional ones. Non-institutional collaborative PD activities tend to be more complex since sometimes the target of the activities are general or less relevant to teachers' needs while institutional collaborative PD activities appear more applicable and focused on problems encountered by teachers. Another difference lies on the possibility and situation in which the institutional PD activities provide more conducive atmosphere to perform with other teachers at school.

The starting point of teachers engaging in professional development in one place may not be relevant to other places. On the other hand, there is a similitude in the processes whereby teachers move from one stage to the next in different contexts that appears to be supported in the research reviewed, although with different manifestations.

In connection with terms of individual PD activities, many literature called as selfinitiated activities. Based on the research on self-initiated activities, Simegn (2014) reveals that the teachers seemed to have higher cognition about the importance of selfinitiated professional development. They acknowledge that the self-driven activities 
and tasks of professionalism act the significant roles in bringing about real change on teachers' pedagogical effectiveness and efficiency.

Based on the findings, there are some individual PD activities that subjects shared. The activities can be in the forms of individual reading, joining online professional community, writing articles and some reflective activities such as self-monitoring and reflective writing journal. Thus, each activity contributes differently for each individual teacher.

Reading activities have the potential to assist in teacher development and some issues related to the result of reading raised can be learnt through sharing and discussing (Pani, 2006). In addition, Murray (2010) points out that the most obvious professional development activity for an English teacher is reading journal articles about teaching English. Thus, reading journals keeps teachers informed about new trends and research developments. In the same vein, reading activities such as printed or non-printed materials by subscribing to magazine or journal is a good way to keep up-to-date with new ideas and themes of the field (Davison, et al. 2012).

In relation to the findings of this study, it shows that reading activity basically emerged from the individual teacher's interest and cognition about the field. With regard to self-directed PD activities, study conducted by Simegn (2014) reveals that for reading activities, teachers tend to spend time for reading based on their needs and interest such as school textbooks, magazines and publication and other books. In relation to this research, teachers also indicate different topics on what they read for instances teaching strategies, classroom management, leaderships and learners' psychology. In sum, reading activities as one strategy of professional development for teachers can be a good means to maintain teachers' competences. Through reading teachers can stay informed with the current matters and get some insights how cope encountered problems.

In addition to reading activities, staying online and joining online language and professional became the most frequent activity that subject did. The data show that all subjects shared the same activity regarding online activities. In addition, they emphasize that online communities provide opportunities for EFL teachers to be active contributors and participants, directing and constructing the learning events for the group and create regular opportunities for enhancing the learning teaching context, and connects teachers to other professionals within and beyond their schools characterized by sustainability over time (Riding, 2001; Saleh \&Pretorius, 2006; Olofsson, 2010)

In the same vein, regarding other advantages of online community, according to Salazar, Muñoz, Fox and Lucas (2010), online and distance professional learning communities provide teachers with increased access and flexibility as well as the combination of work and education. They state that although online environments may present different experiences compared to traditional professional development, they can be used to build knowledge and community and teachers who participate in the program were exposed to new ideas and issues their realm.

To conclude, the current study conducted by Wu, Gao and Zhang (2014) suggest that heterogeneity of community members is crucial for the sustainable and healthy growth of an online professional development community in which participants can establish good relationships among members by sharing ideas, feelings and experiences with people with diverse voices but shared vision of professional pursuits. Another self-directed/individual PD activity that only minority of the subjects conducted was about writing articles and modules. The findings showed two subjects 
wrote some articles and teaching modules. Johnny (2009) points out that writing ranges from short articles right through to books and keeping a diary and reflecting on teaching is a good way to start good writing. By writing some articles and modules, teachers can develop their language skills particularly such as writing skills.

The last self-directed PD activities are related to reflective teaching activities conducted by teachers. Mann (2005) defines implicitly that the notions of reflective practice is the view that teachers develop by studying their own practice, collecting data and using reflective processes as the basis for evaluation and change. Literature show the advantages of reflective teaching activities (Qing, 2009; and Lundy, 2011) the need to implement reflective inquiry in classroom settings and ways to improve the teaching and learning of English through on-going reflection, it also points out that experience coupled with reflection can be a powerful impetus for teacher's professional development. In addition, the reflective process could assist the teachers in understanding how to apply this knowledge in their individual teaching contexts.

In line with them, according Harun and Al-Amin (2013), reflective teaching and action research are really helpful for promoting teachers' professionalism and make classroom practice effective and enjoyable. In relation to this research, the findings show that although merely few subjects conducted reflective teaching activities, they opined that reflective teaching activities can be helpful means to maintain their professionalism. Reflective teaching activities can be in the aspect of self-monitoring through videotaping \& students' feedback and reflective writing journal. Those reflective activities had provided teachers to evaluate what has been done and not to be improved. To draw the conclusion, reflective teaching practice has contributed significantly to the improvement of teachers' quality since they have opportunities to reflect on their knowledge and instruction with the goal of improving both either alone or working with others. Therefore, reflective teaching activities are highly recommended to do for the better and higher professionalism of teachers in education field.

\section{CONCLUSION AND SUGGESTION}

The findings of this research can be considerably categorized into three key ideas of how EFL teachers of two regions Cirebon develop their competencies. It shows that PD activities undertaken by EFL teachers comprise of self-directed/individual, institutional and non-institutional pursuits either in formal or informal situation. The first, self-directed or self-initiated pursuits, refers to individual endeavors that emerge from internal motivation, commitment and cognition of teachers. As a result, the importance of self-initiated professional development activities appeared noticeable in many existing literatures. In addition, self-initiated pursuits can be as comfort means to develop teachers' professionalism since the activities undertaken by teachers are based on their personal interests.

Here are some self-directed activities for teachers that show effective and helpful for maintaining and developing teachers' competencies. The activities are in the form of individual or independent reading, joining online professional communities, writing articles and some reflective activities such as self-monitoring and reflective writing journal. In short, self-directed learning involves personal construction of meaning, uses personal experience as the basis and stimulus for learning; and explores personal teaching practices to solve practice related concerns. 
In addition to self-directed activities, it can be concluded that collaborative institutional (inside school) PD activities have great potential impacts pertinent to better teachers' professionalism. The collegiality of PD built at schools can provide positive atmospheres not only for the individual teacher but also other teachers. By doing groupdirected PD activities, teachers have greater opportunities to discuss and to share with about the latest issues about and English teaching.

It can be concluded that collaborative PD activities turn out to be more effective and favorable than individual PD ones to improve teachers' quality. In this respect, the importance of collegiality and teachers support groups have contributed a lot to help teachers to improve their competencies. It reveals that EFL teachers undertake PD activities institutionally in the form of communication in English with her students \& English teachers, school IHT, informal discussion/conversation, peer observation, peer coaching, and Classroom Action Research (CAR). In addition, these activities have shown positive to development of teachers' competency both pedagogical and professional competencies. However, the most important issue about collaborative institutional PD activities is pertinent to the conducive atmosphere of teachers support groups and informal collegial support existing at the schools.

The last category, collaborative non-institutional PD activities, is the most complex pursuits of teachers' developments. The complexity of the pursuits of development for teachers is attributable to the larger spaces and multifaceted dimension. However, it also can create broad perspectives and provide various insight that may be meaningful and applicable for teachers' needs. Sharing ideas and experiences with other teachers from different institution can be mutually beneficial.

Non-institutional collaborative PD activities include getting involved actively in English teacher forum (MGMP), attending seminars, workshops and other teachers trainings, having language proficiency test, teaching at English course, being a coach and an adjudicator of an English debate, pursuing a further study, having comparative study, implementing lesson study. As has been mentioned previously, more complex activities can create more various benefits for teachers' developments. Therefore, these activities have made up to the development of teachers' professionalism.

There is no recipe for professional development that works for everyone. Frequently teachers find to be an effective tool for them may not offer similar results for other teachers. Techniques that teachers believe useful and meaningful today may not meet teachers' needs a year from now. But what is paramount is that teachers are required to discover many options teachers have for directing their own learning about teaching. Then, proper customization is necessary for the success of programs of teacher learning or professional development. This situation is attributable to the different needs and fast changes in English teaching realms. Therefore, professional development is truly lifelong learning in which teachers are expected to keep up their enthusiasm and motivation to learn the latest issues of the field sustainably.

The first recommendation is addressed to English teachers. In this respect, the English teachers are recommended strongly to consider kinds of PD pursuits because they themselves fully understand what are needed based on the real condition and situations. Thus, both self-directed and group-directed PD pursuits of this research findings are good models for other teachers to be worth conducting. First, teachers should be selective and critical in undertaking a wide range of PD activities since there many PD activities offered are not suitable and relevant for their needs. Second, teachers should be knowledgeable in applying skills and knowledge what they acquire 
from PD activities in the classroom and their own practices. Third, teachers are required to be independent learners to develop their competencies and should be able to place themselves in collaboration with colleagues.

Since the institution (the principal, teachers and administration staffs) plays important roles in maintaining and developing teachers' quality, there are some recommendations that needs to take in consideration from the result of this research. The recommendations are as follows; First, PD activities conducted at schools such as IHT trainings, peer observation/coaching, and discussion or sharing among teachers need to be evaluated more effectively and need to be extended to include the applicability and impact on teachers' performances and quality. Second, the following up activities of teachers training and development should be made available to schools in order to evaluate and to measure the changes in teachers' skills and knowledge. Third, the institution should be cooperative in providing opportunities for all teachers to access a range of PD activities related to the needs of the individual, the school and the local policy such as providing the official permissions and supports. The last, the institution should create conducive and favorable atmosphere in order to maintain teachers' interests and enthusiasm in developing their professionalism and quality through the collegiality built at school.

Literatures suggest that the local authority (the local education department), schools and teachers need to be at the heart of teacher development. As the consequence, it also requires the building of 'strong partnerships' among these parties to create good nuances in pursuits of PD for teachers. Based on the research findings, some important recommendations are required to be considered by local authority.

First, the local authority should be more opened and informed regarding PD activities for teachers and schools. Second, the local authority and the institution must have same visions along with clear guidance for teachers development in order to teachers have distinct targets to achieve. Third, the local education department should occasionally invite qualified trainers and experts to make the programs more interesting and motivating other teachers. Fourth, the local authority should evaluate the existence of subject matters superintendent. Fifth, they should provide a greater opportunity to develop teachers' professionalism in form of the information about scholarships, short courses, and comparative studies and so on. Sixth, the local authority should facilitate sufficient funding and autonomy for teachers in choosing PD activities appropriate to their needs. The last, they should ease the bureaucratic procedures pertaining to PD activities for the local, provincial and national levels for teachers.

This study was conducted with the participation of merely seven English teachers teaching at state junior and senior schools of two areas of Cirebon municipality and Cirebon regency, West Java. There are two main points of limitation in this study. First, this research covers merely small participants of English teachers and small areas of West Java or even Indonesia which is considered as the limitation of the research. Another limitation of the research is related to the focus of the study that cover less specific to particular strategy on teachers' professional development. Therefore, it is highly recommended that future researchers take this present research as the basis to conduct deeper and more specific research regarding English teachers' professional development activities such as individual, institutional, and non-institutional pursuits. 


\section{References}

AL-Wreikat, Y., \& Abdullah, M. 2010. An Evaluation of Jordanian EFL Teachers' Inservice Training Courses Teaching Techniques Effectiveness. English Language Teaching, 3(4), 18-27.

Amin, M. 2013. What Makes Teachers of EFL Professional or Unprofessional. Dissertation, Department of English Language Education, Graduate Program of State University of Malang.

Anugerahwati, M. \& Saukah, A. 2010. Professional Competence of English Teachers in Indonesia: A Profile of Exemplary Teachers. Indonesian Journal of English Language Teaching, 6 (2), 107-117.

Anugerahwati, M. 2009. Professional Competence of English Teachers in Indonesia: A Profile of Exemplary Teachers. Dissertation, Department of English Language Education, Graduate Program of State University of Malang.

Brown, D. 2007. Teaching by Principles: an Interactive Approach to Language Pedagogy $\left(3^{r d} E d\right)$. Englewood Cliffs, N.J.: Prentice-Hall

Chan, G. 2011. The Professional Development of Pre service Teachers in a Postgraduate Diploma in Education Program. Practice and Theory in Systems of Education, 6(2), 185-196.

Davidson, G., Dunlop, F., Soriano. D H., Kennedy, L., \& Philips. T. 2012. Going forward: Continuing Professional Development for English Language Teachers in the UK. British Council.

Harun, M. and Al-Amin, S. 2013. Continuous Teacher Development through Reflective Teaching and Action Research. Bangladesh Research Publications Journal, 8 (1), 69-78.

Hussein, R. 2014. A Profile of Exemplary Teachers of English for Young Learners at the Elementary Schools. Jurnal Pendidikan Humaniora, 2(4), 311-321.

Johnny, J. 2009. Ways to Continuing Professional Development. www.teachingenglish.org.uk/articles/ways-continuing-professional-development, retrieved in April 2012.

Johnson, E., \& Golombek, R. 2011. Research on Second Language Teacher Education: A Sociocultural Perspective on Professional Development. New York: Routledge.

Karimi, N. 2011. The Effects of Professional Development Initiatives on EFL Teachers' Degree of Self Efficacy. Australian Journal of Teacher Education, 36(6), 50-62.

Kasi, F. 2011. Collaborative Action Research: An Alternative Model for EFL. The Asian EFL Journal Quarterly, 12(3), 98-117.

Kazemi, A., \& Ashrafi, M. 2014. In-Service Training Programs for Iranian EFL Teachers Revisited. International Journal of Asian Social Science, 4(10), 10621076.

Khan, A. 2011. Professional Development of English Teachers: The Saudi Arabian Context. Interdisciplinary Journal of Contemporary Research in Business, 3(2), 1583-1591.

Kolo, C. 2006. Portrait of a Good EFL Teacher: A Study on Teachers' Perspectives. Dissertation, Department of English Language Education, Graduate Program of State University of Malang.

Lay, C. 2010. EFL Teacher Workshops on Classroom Management and Increasing Classroom Interaction in Cambodia. Paper presented in E-Teacher Professional Development Workshop University of Maryland Baltimore County and University of Oregon. 
Lee, I. 2011. Teachers as Presenters at Continuing Professional Development Seminars in the English as a Foreign Language Context: 'I find it more convincing'. Australian Journal of Teacher Education, 36(2), 30-42.

Liando, N. 2010. Students' Vs. Teachers' Perspectives on Best Teacher Characteristics in EFL Classrooms. TEFLIN Journal, 21(2),118-136.

Mann, S. 2005. The Language Teacher's Development. Language Teaching. 38, 103118. Cambridge: Cambridge University Press.

Meng, J \& Tajaroensuk, S. 2013. The Workshop in the Multilayered Peer Coaching Model for Tertiary EFL Teachers' In-Service Professional Development. English Language Teaching, 6 (8), 44-53.

Murray, D. \& Cristinson, M. 2011. What English Language Teachers Need to Know Volume I - Understanding Learning. New York: Routledge.

Murray, A. 2010. Empowering Teachers through Professional Development. English Teaching Forum 1, 2-11.

Mustofa, M. 2011. Professional Development of EFL Teachers at Vocational schools. Dissertation, Department of English Language Education, Graduate Program of State University of Malang.

Olofsson, A. 2010. Discussions in Online Learning Community Forums- Do They Facilitate Teachers Professional Development?. The University of the Fraser Valley Research Review, 3(2), 54-68.

Pani, S. 2006 Teacher Development through Reading Strategy Instruction: The Story of Supriya. TESL-EJ 10(2), 1-21.

Ramadhani, N., Ancok, D., Swasono, Y., \& Suryanto, P. 2012. Teacher Quality Improvement Program: Empowering Teachers to Increasing a Quality of Indonesian's Education. Proceeding of International Conference on Education and Educational Psychology. Istanbul, Turki. 10-13 October 2012.

Raza, N. 2010. The Impact of Continuing Professional Development on EFL Teachers Employed in Federal Universities in the United Arab Emirates. Unpublished Dissertation, The University of Exeter.

Richards, J. \& Farrell, T. 2005. Professional Development for Language Teachers. Strategies for Teacher Learning. Cambridge: Cambridge University Press.

Riding, P. 2001. Online Teacher Communities and Continuing Professional Development. Teacher Development, 5(3),283-295.

Rodríguez, A \& McKay, S. 2010. Professional Development for Experienced

Teachers Working With Adult English Language Learners. The U.S. Department of Education, Office of Vocational and Adult Education.

Salazar, D., Muñoz, Z., Fox, K., \& Lucas, L. 2010. On-line Professional Learning Communities: Increasing Teacher Learning and Productivity in Isolated Rural Communities. Systemics, Cybernetics and Informatics, 8(4), 1-7.

Saleh, S. \& Pretorius, F. 2006. English as a Foreign Language: Teachers' Professional Development via the Internet. Progressio, 28, (1\&2) 111-126.

Simegn, B. 2014. EFL Teachers' Self-Initiated Professional Development: Perceptions and practices. Academic Journal, 9(21), 1109-1114.

Su, T., Yang, Y., \& Hsioa, Y. 2010. The Strategies of Professional Development for the EFL Teachers in Elementary Schools. Journal of Management Science \& Statistical Decision, 7(4), 1-14.

Tasker, T. 2011. Teacher Learning through Lesson Study: An Activity Theoretical Approach toward Professional Development in the Czech Republic. In K. E 
Johnson, \& P. R Golombek (Eds), Research on Second Language Teacher Education: A Sociocultural Perspective on Professional Development. New York: Routledge.

Wati, H. 2011. The Effectiveness of Indonesian English Teachers Training Programs in Improving Confidence and Motivation. International Journal of Instruction, 4(1), 79-104.

Wichadee, S. 2011. Professional Development: A Path To Success For EFL Teachers. Contemporary Issues in Education Research, 4(5), 13-22.

Wu, H., Gao, J., \& Zhang, W. 2014. Chinese EFL Teachers' Social Interaction and Socio-Cognitive Presence in Synchronous Computer-Mediated Communication. Language Learning \& Technology, 18(3), 228-254.

Qing, X. 2009. Reflective Teaching: an Effective Path for EFL Teacher's Professional Development. Canadian Social Science, 5(2), 35-40.

Zuheer, K. 2013. Developing EFL Teachers' Performance at Sana'a Secondary Schools in the Light of their Professional and Specialist Needs. Dissertation, Institute of Educational Studies Curriculum \& Instruction Department, Cairo University. 